Suci Fitria Sari \& Joko Sutrisno : Penurunan Total Coliform Pada Air Tanah Menggunakan Membran Keramik

\title{
PENURUNAN TOTAL COLIFORM PADA AIR TANAH MENGGUNAKAN MEMBRAN KERAMIK
}

\author{
Suci Fitria Sari ${ }^{1)}$ dan Joko Sutrisno ${ }^{2)}$ \\ ${ }^{1)}$ Program Studi Teknik Lingkungan, Fakultas Teknik Sipil dan Perencanaan, \\ Universitas PGRI Adi Buana Surabaya \\ Email : jsutrisno@unipasby.ac.id
}

\begin{abstract}
Abstrak
Peningkatan pertumbuhan jumlah penduduk memberikan tekanan besar terhadap jumlah ketersediaan sumber air. Masyarakat di beberapa daerah yang belum terfasilitasi air bersih dari PDAM menggunakan air tanah sebagai salah satu sumber air bersih. Masalah yang sering dijumpai adalah kualitas air tanah yang belum memenuhi syarat sebagai air bersih berdasarkan Permenkes RI No. 416 Tahun 1990, termasuk air tanah di Dukuh Menanggal Surabaya yang memiliki kandungan total coliform di atas baku mutu. Penelitian dilakukan untuk menurunkan total coliform menggunakan membran keramik. Penelitian ini memiliki tujuan mengetahui a.) pengaruh perbandingan komposisi membran keramik terhadap kemampuan filtrasi total coliform, b.) kemampuan membran keramik dalam menurunkan total coliform. Membran keramik berbentuk piringan dengan diameter $10 \mathrm{~cm}$ dan ketebalan 1,5 cm. Variasi komposisi membran keramik yang akan diuji adalah komposisi I yaitu tanah liat 60\%, sekam padi 20\%, zeolit 20\% dan komposisi II yaitu tanah liat 50\%, sekam padi $20 \%$, zeolit 30\%. Hasil penelitian menunjukan bahwa membran keramik dengan komposisi tanah liat 50\%, sekam padi $20 \%$, dan zeolit $30 \%$ mampu menurunkan nilai total coliform lebih baik dibandingkan membran keramik dengan komposisi tanah liat 60\%, sekam padi 20\%, dan zeolit 20\%. Membran keramik dengan komposisi tanah liat 50\%, sekam padi 20\%, dan zeolit 30\% mampu menurunkan nilai total coliform sebesar $230 \mathrm{MPN} / 100 \mathrm{ml}$, sedangkan membran keramik dengan komposisi tanah liat 60\%, sekam padi 20\%, dan zeolit 20\% mampu menurunkan nilai total coliform sebesar $226 \mathrm{MPN} / 100 \mathrm{ml}$.
\end{abstract}

Kata kunci: air bersih, membran keramik, total coliform

\begin{abstract}
Increasing population growth gives enormous pressures on the amount of the availability of water sources. Communities in several districts that have not facilitated clean water supply generally using groundwater as one source of clean water. A problem that is often found the quality of ground water has not qualify as clean water based on Permenkes RI No. 416 Tahun 1990, including groundwater in dukuh menanggal surabaya has any bacteria total coliform on of quality standard. This study to reduce total coliform use ceramic membrane. This study has objective to know a.) the comparison composition ceramic membrane faith in capacity of filtration total coliform, b.) ability of ceramic membrane to reduce total coliform. Ceramic membrane disk shaped 10 inches in diameter and thickness $1,5 \mathrm{~cm}$. Variations membrane ceramic composition to be tested is a composition I that is clay 60\%, a rice husk $20 \%$, a zeolite $20 \%$ and composition II that is clay 50\%, a rice husk 20\%, a zeolite 30\%. The results showed that ceramic membrane with the composition of clay $50 \%$, a rice husk $20 \%$, and the zeolites $30 \%$ to reduce total coliform better than ceramic membrane with the composition of clay $60 \%$, a rice husk $20 \%$, and the zeolites $20 \%$. Ceramic membrane with the composition of clay $50 \%$, a rice husk $20 \%$, and the zeolites $30 \%$ to reduce total coliform of $230 \mathrm{mpn}$ / $100 \mathrm{ml}$, while ceramic membrane with the composition of clay $60 \%$, a rice husk $20 \%$, and the zeolites $20 \%$ to reduce total coliform of $226 \mathrm{mpn} / 100 \mathrm{ml}$.
\end{abstract}

Keywords: clean water, ceramic membrane, total coliform 



\section{PENDAHULUAN}

Kelurahan Dukuh Menanggal Surabaya memanfaatkan air tanah sebagai sumber air bersih, namun kualitas air tersebut belum memenuhi baku mutu air bersih di parameter total coliform seuai yang ditetapkan Permenkes RI No. 416 Tahun 1990. Diperlukan upaya pengolahan untuk menurunkan nilai total coliform yang terdapat dalam air tanah agar memiliki kualitas yang sesuai dengan baku mutu air bersih. Teknologi membran merupakan salah satu cara atau metode yang sering digunakan karena prosesnya relatif sederhana dan bahan-bahannya mudah diperoleh. Sehingga tujuan pada penelitian ini adalah untuk mengetahui:

1. Pengaruh variasi perbandingan komposisi tanah liat, sekam padi, dan zeolit sebagai membran keramik untuk menurunkan total coliform dalam air tanah.

2. Kemampuan membran keramik berbasis tanah liat, sekam padi, dan zeolit dalam menurunkan total coliform pada air tanah.

\section{Air Bersih}

Air bersih adalah air yang memenuhi syarat kesehatan dan harus dimasak terlebih dahulu sebelum diminum. Air bersih dalam hal ini air tanah terkadang mengalami pencemaran. Pencemaran air tanah umumnya terjadi oleh tingkah laku manusia seperti oleh zat-zat detergen, asam belerang dan zatzat kimia sebagai sisa pembuangan pabrik-pabrik kimia/industri. Pencemaran air juga disebabkan oleh pestisida, herbisida, pupuk tanaman yang merupakan unsur-unsur polutan sehingga mutu air berkurang (Supardi, 2003). Syarat kualitas air bersih sesuai peruntukannya juga telah diatur dalam berbagai peraturan tertulis. Kualitas air bersih yang dinyatakan aman harus memenuhi baku mutu sesuai Permenkes RI Nomor 416/Menkes/Per/IX/1990 dengan salah satu parameternya yakni total coliform sebesar 10 MPN/100ml.

\section{Bakteri Coliform}

Bakteri Coliform merupakan bakteri indikator kehadiran bakteri patogen dan memiliki ketahanan paling besar terhadap desinfektan (Servais et al, 2007). Bakteri coliform yang dinyatakan sebagai nilai total coliform dapat digunakan sebagai indikator karena berbanding lurus dengan pencemaran air, semakin sedikit kandungan coliform artinya kualitas air semakin baik.

\section{Membran Keramik}

Membran merupakan suatu lapisan tipis di antara dua fasa fluida yaitu fasa umpan (feed) dan fasa permeat yang berfungsi sebagai penghalang (barrier) terhadap suatu partikel tertentu. Membran bersifat semipermeabel, berarti membran dapat menahan spesi-spesi tertentu yang lebih besar dari ukuran pori membran dan melewatkan spesi-spesi lain dengan ukuran lebih kecil (Notodarmojo dan Anne, 2004). Keramik adalah suatu bentuk dari tanah liat yang telah mengalami proses pembakaran (Nasir dan Teguh 2011). Kelebihan membran keramik terletak pada stabilitas termal yang baik, memiliki ketahanan terhadap senyawa kimia dan degradasi biologis ataupun mikroba, dan relatif mudah untuk dibersihkan dengan cleaning agent.

Komposisi bahan pembuatan membran keramik antara lain tanah liat, sekam padi, dan zeolit. Menurut Urabe (2006), tanah liat alam merupakan material yang berpori sehingga memiliki kemampuan untuk mengadsorpsi serta memiliki ion yang bisa dipertukarkan dengan ion dari luar.

Sekam padi yang dihaluskan dengan mesin penepung digunakan sebagai bahan pengisi yang terbakar habis sewaktu pembakaran dan meninggalkan alur-alur halus. Ukuran butiran sekam padi akan mempengaruhi kecepatan aliran dan kekuatan elemen filter.

Penambahan zeolit sebagai media adsorben dalam membran keramik meningkatkan kemampuan membran keramik dalam menurunkan kadar polutan dalam air. Penggunaan zeolit 
secara komersial adalah berdasarkan salah satu atau lebih dari kemampuan sifat-sifat fisik atau kimia yang dimilikinya, antara lain (1) pertukaran ion, (2) adsorbsi dan sifat penyaring molekuler, (3) katalisis, (4) dehidrasi, dan rehidrasi (Wigayati dan Sebayang, 1997).

\section{METODE}

Metode yang digunakan dalam penelitian ini adalah eksperimen dengan perlakuan membran keramik dibuat dengan dua variasi yaitu variasi I tanah liat $60 \%$, sekam padi $20 \%$, dan zeolit $20 \%$, sedangkan variasi II tanah liat $50 \%$, sekam padi $20 \%$, dan zeolit $30 \%$ dengan perbandingan persen volume, kemudian menganalisa nilai total coliform pada air tanah yang telah melewati membran keramik. Populasi dalam penelitian ini adalah air bersih di Kelurahan Dukuh Menanggal Surabaya. Rancangan kegiatan penelitian digambarkan pada gambar 1.

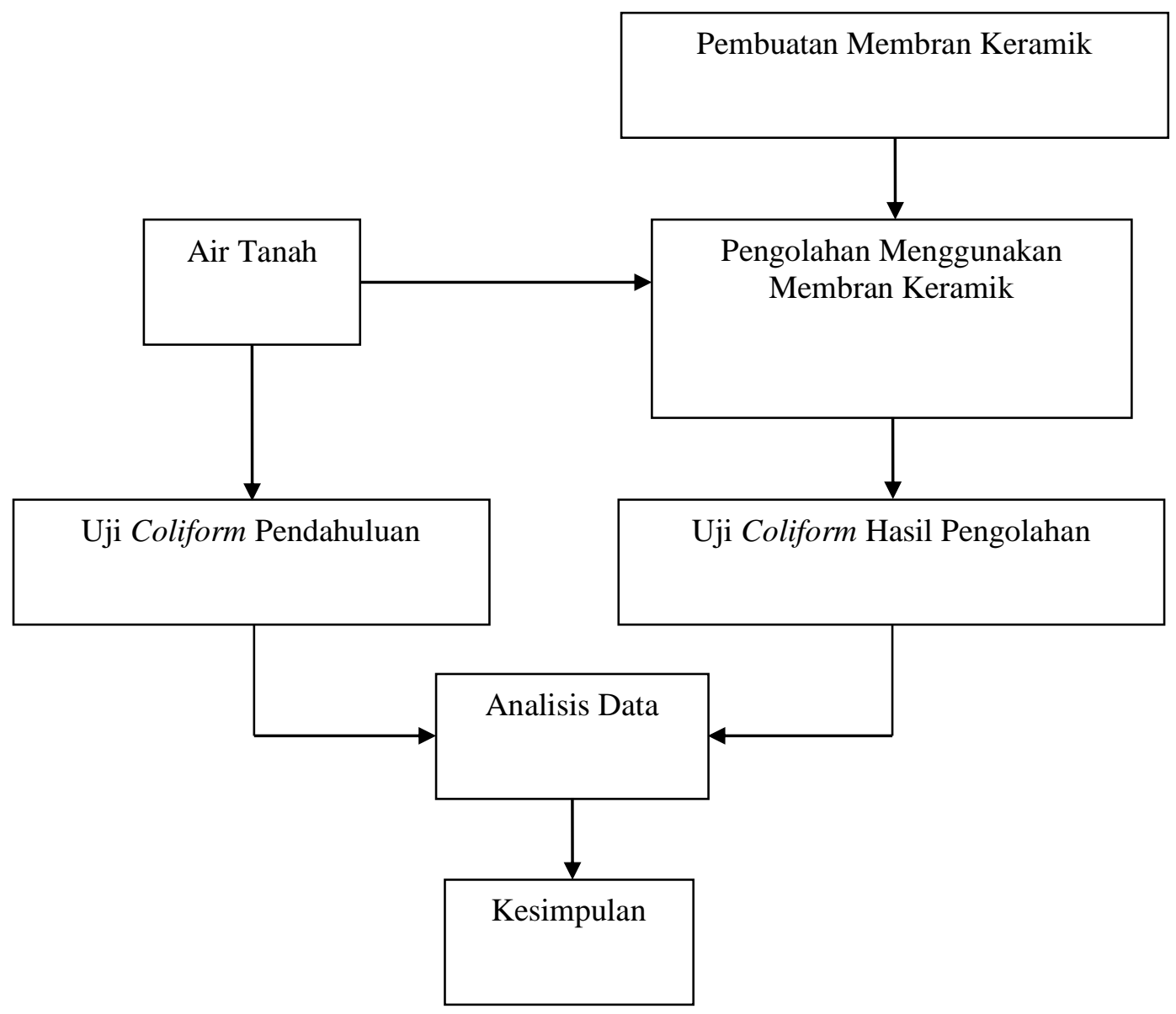

Gambar 1. Rancangan Penelitian

Variabel Terikat

- Nilai total coliform sebagai parameter air bersih (Metode Multiple tube APHA9221.B.Ed.21.2005)

\section{Variabel Bebas}

- Komposisi campuran bahan pembuatan membran keramik :
Variabel Kontrol

- Suhu pembakaran/sintering membran keramik $600{ }^{\circ} \mathrm{C}$

- Ketebalan membran keramik 1,5 cm

- Keramik dicetak dengan bentuk piringan berdiameter $10 \mathrm{~cm}$

- Ketinggian air selama penelitian $1 \mathrm{~m}$ 


\section{Desain Alat Penelitian}

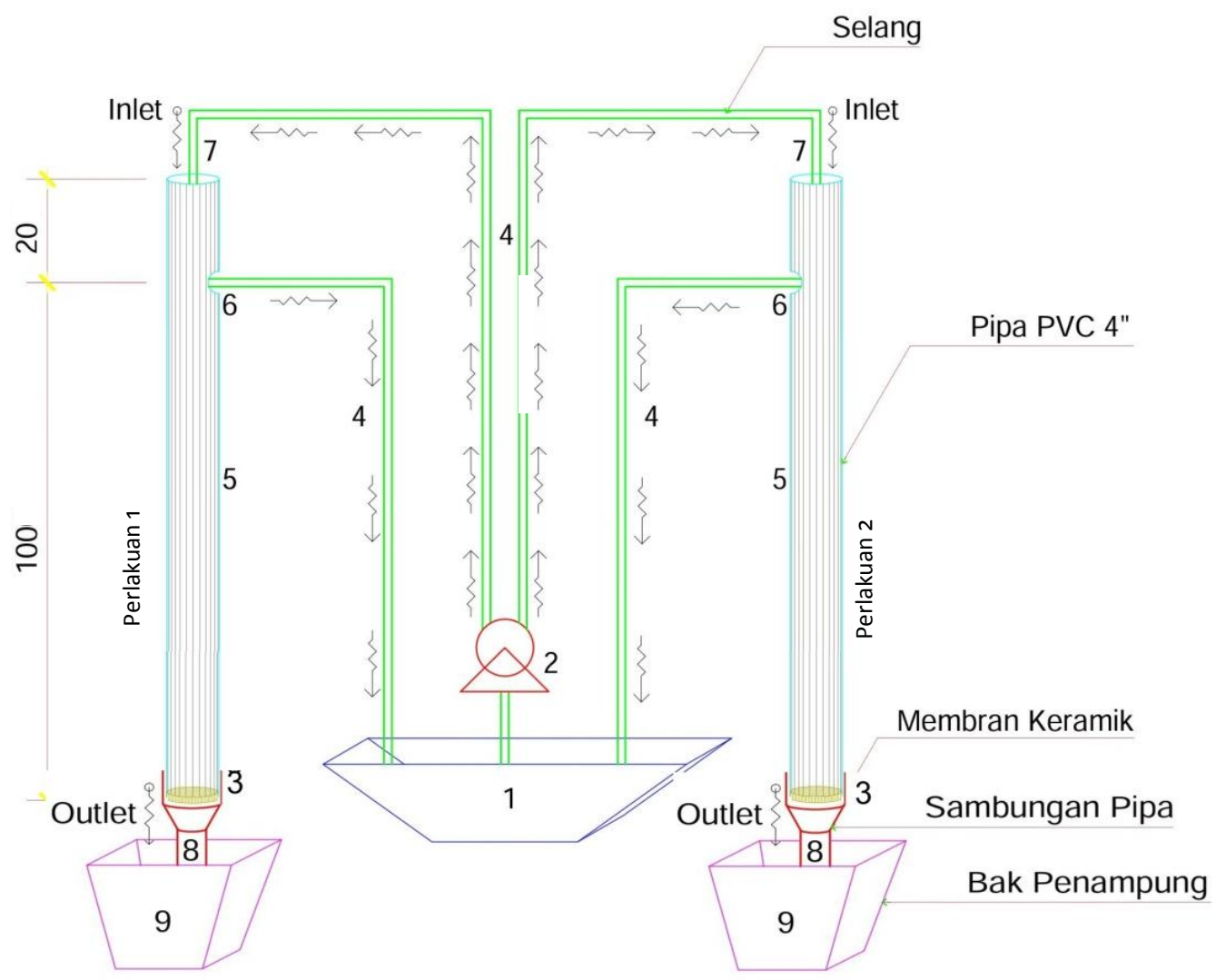

Gambar 2. Desain Alat Penelitian

Keterangan :

1. Bak penampung air baku

2. Pompa

3. Membran keramik, diameter $10 \mathrm{~cm}$, ketebalan $1,5 \mathrm{~cm}$

4. Selang plastik 1,5 "

5. Pipa PVC 4", ketinggian $120 \mathrm{~cm}$

6. Pengatur ketinggian air $(100 \mathrm{~cm})$

7. Inlet

8. Outlet

9. Bak penampung hasil olahan

Alat dan bahan yang digunakan dalam penelitian ini adalah sebagai berikut:

a. Alat

1. Botol sampel steril

2. Furnace
3. Mesin ayakan

4. Gelas ukur

5. Pipa

6. Pompa

7. Bak penampung

8. Peralatan uji parameter total coliform

b. Bahan

1. Tanah liat

2. Sekam padi

3. Zeolit

4. Sampel air bersih Kelurahan Dukuh Menanggal Surabaya

5. Aquades

6. Bahan uji parameter total coliform

Prosedur Pembuatan Membran
Keramik 
Tahap prosedur pembuatan membrane keramik adalah sebagai berikut:

1. Tanah liat diiris tipis-tipis, lalu dijemur selama 7 hari, lalu ditumbuk dan diayak menjadi tepung dengan ukuran 35 mesh

2. Bahan aditif (zeolit) yang masih berukuran kasar dihaluskan hingga menjadi serbuk halus lalu diayak dengan ukuran 35 mesh

3. Tanah liat dan bahan aditif (sekam padi dan zeolit) dicampur merata dengan perbandingan $\%$ volume masingmasing perlakuan I (60:20:20) dan perlakuan II (50:20:30)

4. Sedikit air ditambahkan ke dalam adonan membran dan sambil diaduk rata

5. Adonan membran dicetak dengan cetakan membrane berbentuk disk dengan diameter $13 \mathrm{~cm}$ dan tebal 2,5 $\mathrm{cm}$ untuk memperkirakan susut pada saat proses pembuatan

6. Adonan dikeluarkan dari cetakan membran, kemudian dikeringkan pada temperatur kamar selama 7 hari

7. Membran dibakar pada suhu $600^{\circ} \mathrm{C}$ selama 5 jam. Hasil akhir dari pembuatan membrane seperti pada gambar 3 berikut.

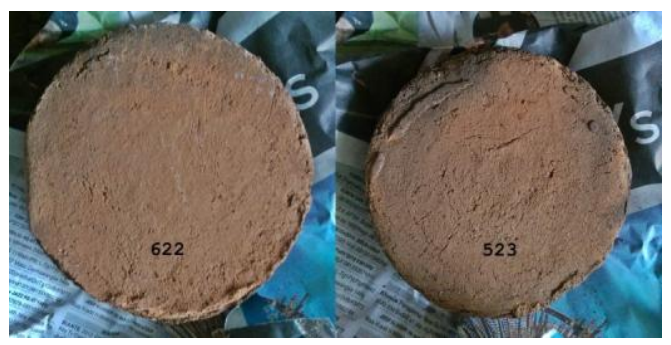

Gambar 3. Membran Keramik

\section{Pelaksanaan Penelitian}

1. Menyiapkan alat dan bahan yang dibutuhkan

2. Mencuci membran keramik dengan melakukan penyaringan menggunakan aquades terlebih dahulu dengan maksud untuk membilas dan membersihkan kotoran sisa pembakaran.

3. Sampel air dimasukkan ke dalam bak penampung yang sudah dihubungan dengan unit filtrasi menggunakan selang
4. Menghidupkan pompa yang berfungsi untuk menjaga debit aliran sampel

5. Output hasil filtrasi diambil setiap 2 jam selama 6 jam sebagai sampel untuk dianalisis kualitasnya setelah melewati membran.

6. Langkah yang sama dilakukan untuk variasi yang berbeda.

7. Dilakukan pengulangan sebanyak tiga kali

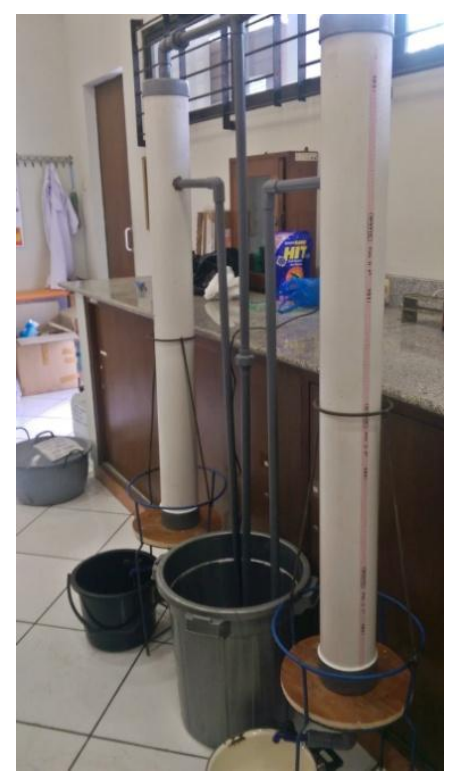

Gambar 4. Rangkaian Alat Penelitian

\section{Pengumpulan Data}

Data yang dikumpulkan adalah volume air yang berhasil tersaring dalam satuan waktu yang diukur dengan gelas ukur dan hasil analisis kualitas air tanah sebelum dan sesudah melewati membran keramik pada parameter total coliform yang diuji dengan metode Multiple tube APHA9221.B.Ed.21.2005.

Pengumpulan data sampel hasil pengolahan dilakukan dengan pengambilan sampel air setiap 2 jam sebanyak tiga kali dalam sehari selama 3 hari dengan replikasi analisis parameter uji sebanyak dua kali. Analisis data dilakukan secara statistika deskriptif dalam bentuk grafik. 
Suci Fitria \& Joko Sutrisno : Penurunan Total Coliform Pada Air Tanah Menggunakan Membran Keramik

\section{HASIL DAN PEMBAHASAN}

Hasil penelitian beserta pembahasannya disajikan sebagai berikut :

\section{Hasil Pembuatan Membran Keramik}

Komposisi membran keramik divariasikan, variasi yang pertama adalah tanah liat $60 \%$, sekam padi $20 \%$, dan zeolit $20 \%$ (622). Variasi yang kedua adalah tanah liat $50 \%$, sekam padi 20\%, dan zeolit 30\% (523). Perbandingan komposisi bahan membran keramik ditetapkan berdasarkan prosentasi volume bahan.

Tabel 1. Komposisi Bahan Pembuatan Membran

\begin{tabular}{cccc}
\hline \multirow{2}{*}{ Kode Membran } & \multicolumn{3}{c}{ \% Komposisi Bahan } \\
\cline { 2 - 4 } & Tanah Liat & Sekam Padi & Zeolit \\
\hline 622 & 60 & 20 & 20 \\
523 & 50 & 20 & 30 \\
\hline
\end{tabular}

\section{Debit Filtrasi}

Data debit filtrasi didapatkan dari pengukuran volume air hasil saring yang dikonversikan menjadi satuan liter per hari. Grafik perbandingan filtrasi masing-masing membran keramik adalah seperti pada gambar 5 sebagai berikut :

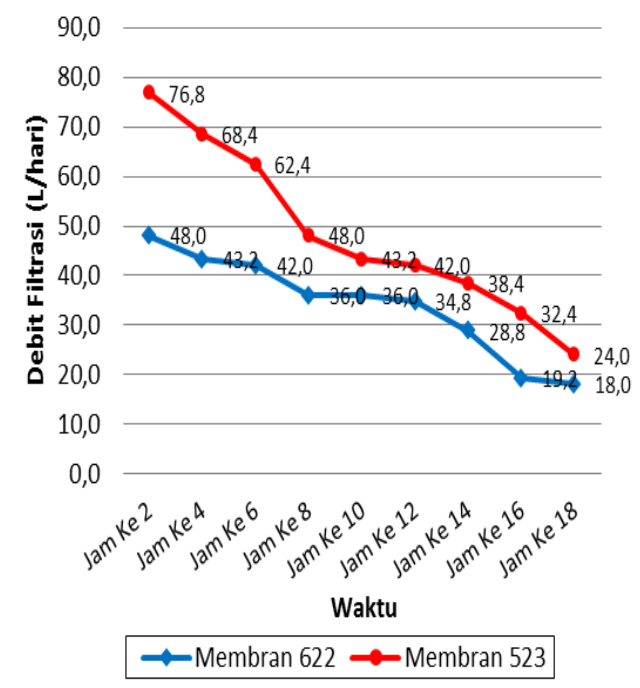

Gambar 5. Grafik Debit Filtrasi

Membran keramik 622 dengan komposisi tanah liat $60 \%$, sekam padi $20 \%$, dan zeolit $20 \%$ pada jam ke-2 yaitu pada hari pertama di dua jam pertama mampu menyaring air baku dengan debit $48 \mathrm{~L} /$ hari, kemudian terus menurun hingga di jam ke-18 yaitu pada hari ketiga di dua jam ketiga mampu menyaring air baku dengan debit 18L/hari. Sedangkan Membran keramik 523 dengan komposisi tanah liat $50 \%$, sekam padi $20 \%$, dan zeolit $30 \%$ mampu menyaring air dengan debit lebih besar dari membran keramik 622, pada jam ke-2 yaitu pada hari pertama di dua jam pertama mampu menyaring air baku dengan debit $76,8 \mathrm{~L} / \mathrm{hari}$, kemudian terus menurun hingga di jam ke-18 yaitu pada hari ketiga di dua jam ketiga mampu menyaring air baku dengan debit 24L/hari.

Penurunan yang terjadi disebabkan adanya endapan-endapan berupa logam dan mikroorganisme yang menghambat laju filtrasi air sehingga pada waktu tertentu terjadi proses kejenuhan. Ketika debit filtrasi dirasa semakin tidak memenuhi kebutuhan maka membran keramik dapat diaktivasi lagi (Febrina dan Ayuna, 2014).

\section{Nilai Total Coliform}

Analisis data nilai total coliform disajikan berupa nilai total coliform pada air tanah sesudah melewati membran keramik, nilai total coliform yang berhasil disisihkan oleh membran keramik, serta besar efisiensi membran keramik dalam menurunkan total coliform. Nilai total coliform hasil uji laboratorium terhadap air tanah yang belum melewati membran keramik disajikan dalam tabel 2.

Tabel 2. Nilai Total Coliform Sebelum Melewati Membran Keramik

\begin{tabular}{c|c}
\hline Nama Sampel & $\begin{array}{c}\text { Total Coliform } \\
\text { (MPN/100ml) }\end{array}$ \\
\hline $\begin{array}{c}\text { Air Tanah Dukuh } \\
\text { Menanggal } \\
\text { Surabaya }\end{array}$ & 240 \\
\hline
\end{tabular}


Suci Fitria Sari \& Joko Sutrisno : Penurunan Total Coliform Pada Air Tanah Menggunakan Membran Keramik

Hasil analisis data total coliform setelah melewati membran keramik dapat dilihat pada gambar 6 .
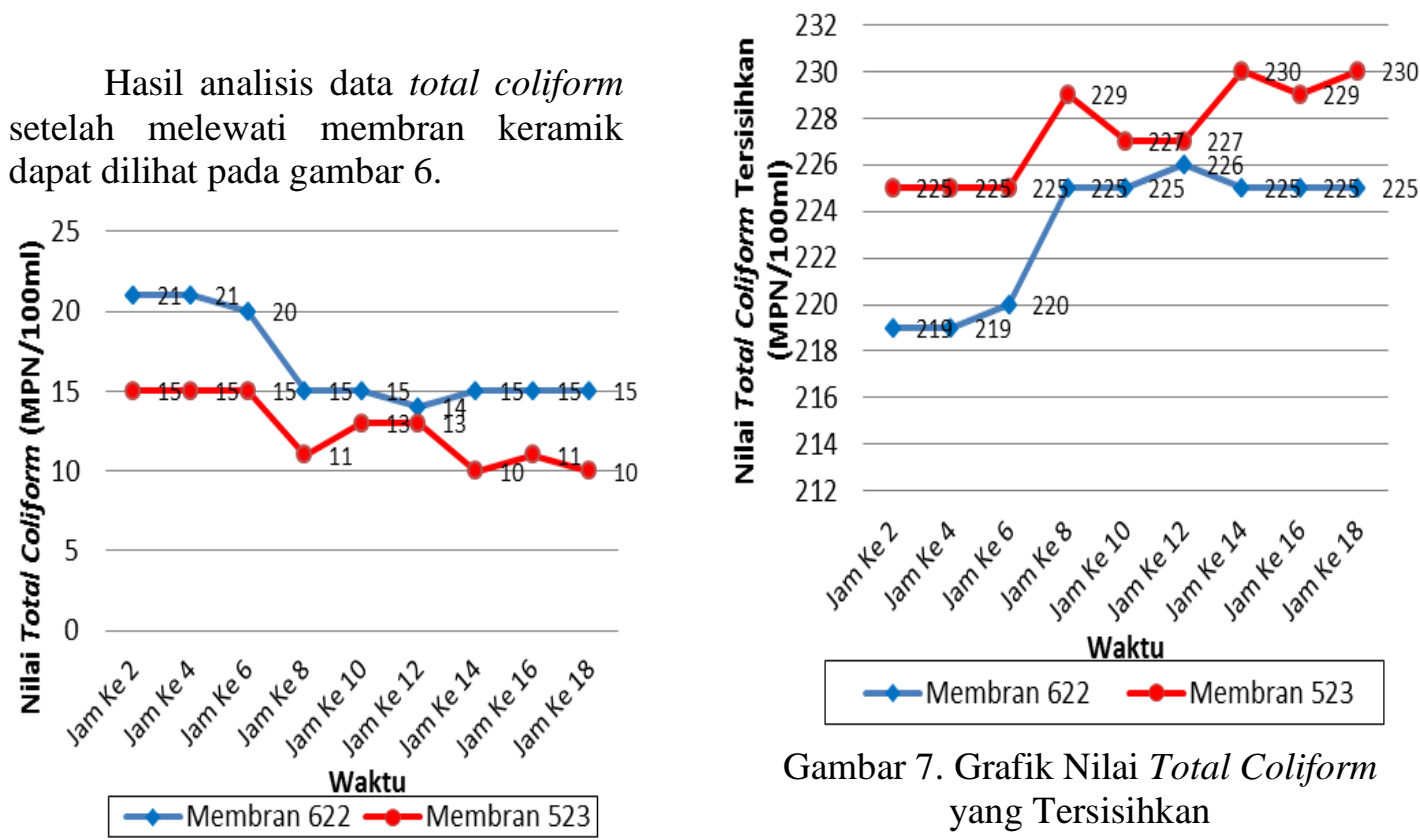

Gambar 7. Grafik Nilai Total Coliform yang Tersisihkan

Gambar 6. Grafik Nilai Total Coliform Setelah Melewati Membran Keramik

Nilai total coliform air hasil saring membran 622 dengan komposisi tanah liat $60 \%$, sekam padi $20 \%$, dan zeolit 20\% terkecil didapatkan pada pengambilan sampel di jam ke-12 yaitu pada hari kedua di dua jam ketiga sebesar 14 MPN/100ml, sedangkan kadar terbesar didapatkan pada pengambilan sampel di jam ke-2 dan 4 yaitu pada hari pertama di dua jam pertama dan kedua sebesar 21 MPN/100ml. Sedangkan nilai total coliform air hasil saring membran 523 dengan komposisi tanah liat $50 \%$, sekam padi $20 \%$, dan zeolit $30 \%$ terkecil didapatkan pada pengambilan sampel di jam ke-14 dan 18 yaitu pada hari ketiga di dua jam pertama dan ketiga sebesar 10 MPN/100ml dan telah memenuhi baku mutu air bersih di parameter total coliform sesuai Permenkes RI No. 416 Tahun 1990, sedangkan kadar terbesar didapatkan pada pengambilan sampel di jam ke-2, 4, dan 8 yaitu pada hari pertama di dua jam pertama, kedua, dan ketiga sebesar $15 \mathrm{MPN} / 100 \mathrm{ml}$.

Analisis data nilai total coliform yang berhasil disisihkan oleh masingmasing jenis membran dapat dilihat pada gambar 7 .

Hasil analisis data efisiensi penurunan nilai total coliform pada air hasil saring masing-masing membran keramik disajikan pada gambar 8 .

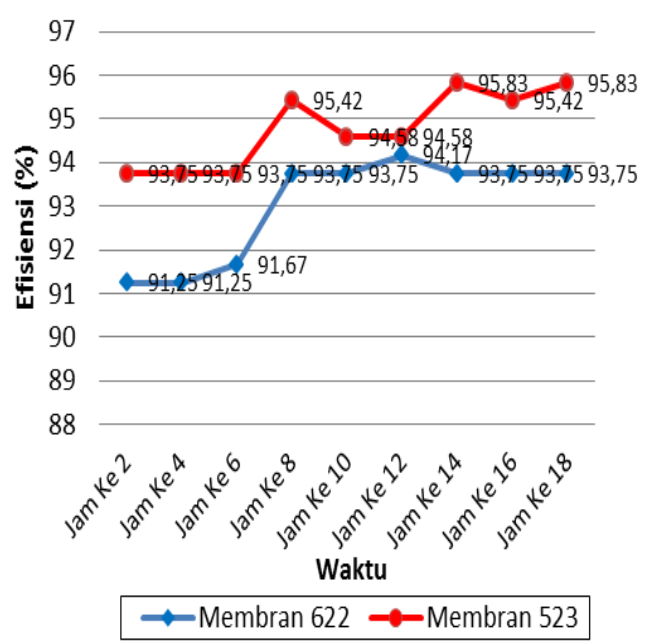

Gambar 8. Grafik Efisiensi Penurunan nilai Total Coliform

Efisiensi penurunan nilai total coliform membran 523 dengan komposisi tanah liat $50 \%$, sekam padi $20 \%$, dan zeolit $30 \%$ terkecil didapatkan pada pengambilan sampel di jam ke-2, 4, 6 yaitu pada hari pertama di dua jam pertama, kedua, dan ketiga yaitu sebesar 93,75\%, sedangkan efisiensi tertinggi didapatkan pada pengambilan sampel di jam ke-14 dan 18 yaitu pada hari ketiga di dua jam 
pertama dan ketiga yaitu sebesar $95,83 \%$. Sedangkan efisiensi penurunan nilai total coliform membran 622 dengan komposisi tanah liat $60 \%$, sekam padi $20 \%$, dan zeolit $20 \%$ terkecil didapatkan pada pengambilan sampel di jam ke-2 dan 4 yaitu pada hari pertama di dua jam pertama dan kedua sebesar $91,25 \%$, sedangkan efisiensi tertinggi didapatkan pada pengambilan sampel di jam ke-12 yaitu pada hari kedua di dua jam ketiga sebesar $94,17 \%$. Wongsakoonkan (2014) mampu menurunkan nilai total coliform dan E.coli pada air tanah dengan efisiensi hingga $100 \%$ menggunakan membran keramik dari campuran tanah liat dengan pasir, arang sekam padi, dan arang batok kelapa dengan suhu dan lama pembakaran yang sama dengan penelitian ini, namun efisiensi yang didapatkan lebih tinggi. Sedangkan Widodo (2012) membuat mebran keramik dengan bahan campuran tanah liat dan serbuk gergaji digunakan untuk menyaring mata air dan berhasil menurunkan nilai total coliform dengan efisiensi $100 \%$. Kasam, pada tahun 2009 berhasil menurunkan bakteri coliform mencapai 98\% dengan membran berbasis tanah liat, pasir kwarsa, dan serbuk gergaji dengan suhu pembakaran $1200{ }^{\circ} \mathrm{C}$. Perbedaan perlakuan dan komposisi membran keramik serta suhu pembakaran berpengaruh terhadap kemampuan membran keramik dalam menurunkan total coliform

$$
\text { Semakin banyaknya }
$$

perbandingan komposisi zeolit dalam membran keramik maka semakin tinggi efisiensi membran keramik tersebut karena kemampuan zeolit sebagai adsorben total coliform lebih baik dibandingkan tanah liat saja, sehingga pada membran keramik 523 meskipun perbandingan komposisi tanah liat lebih sedikit tetapi kemampuan membran keramik tersebut dalam menurunkan nilai total coliform sangat terbantu dengan komposisi zeolit yang lebih besar dibandingkan membran keramik 622.

\section{KESIMPULAN}

Dari hasil penelitian ini dapat disimpulkan bahwa :

1. Membran keramik dengan komposisi tanah liat 50\%, sekam padi $20 \%$, dan zeolit $30 \%$ memiliki efisiensi lebih besar dalam menurunkan nilai total coliform pada air tanah dibandingkan membran keramik dengan komposisi tanah liat $60 \%$, sekam padi $20 \%$, dan zeolit $20 \%$.

2. Membran keramik dengan komposisi tanah liat 50\%, sekam padi $20 \%$, dan zeolit $30 \%$ mampu menurunkan nilai total coliform hingga $230 \quad$ MPN/100ml, sedangkan membran keramik dengan komposisi tanah liat 60\%, sekam padi $20 \%$, dan zeolit $20 \%$ mampu menurunkan nilai total coliform sebesar $226 \mathrm{MPN} / 100 \mathrm{ml}$.

\section{Ucapan Terima Kasih}

Penelitian ini telah mendapatkan dukungan peralatan dan bahan analisis sampel dari laboratorium Teknik Lingkungan Universitas PGRI Adi Buana (UNIPA) Surabaya. Selain itu ucapan terima kasih disampaiakn kepada Muhammad Al Kholif yang telah banyak membantu dan membimbing dalam penulisan artikel ilmiah untuk dipublikasikan di Jurnal WAKTU Teknik.

\section{DAFTAR PUSTAKA}

Febrina, Laila dan Ayuna, Astrid.2014.Studi Penurunan Kadar Besi (Fe) Dan Mangan (Mn) Dalam Air Tanah Menggunakan Saringan Keramik. Jurnal Teknologi. Jurusan Teknik Lingkungan, Universitas Sahid, Jakarta. 
Suci Fitria Sari \& Joko Sutrisno : Penurunan Total Coliform Pada Air Tanah Menggunakan Membran Keramik

Kasam, Siswoyo, E. 2009. Penggunaan Membran Keramik untuk Menurunkan Bakteri E. Coli dan Total Suspended Solid (TSS) Pada Air Permukaan, Jurnal Sains dan teknologi Lingkungan, Vol. 1 No. 1, ISSN: 2085-1227

Nasir, S dan Teguh Budi SA. 2011. Pengolahan Air Limbah Hasil Proses Laundry Menggunakan Filter Keramik Berbahan Tanah Liat Alam dan Zeolit, Laporan Hibah Kompetitif 2011, Universitas Sriwijaya, Indralaya

Notodarmojo, Supriharton dan Anne Deniva. 2004. Penurunan zat Organik dan Kekeruhan menggunakan Teknologi Membran Ultrafiltrasi dengan Sistem aliran Deat-End

Peraturan Menteri Kesehatan Nomor 416/MENKES/PER/IX/1990 tentang Syarat-syarat dan Pengawasan Kualitas Air

Servais, Pierre. Et al. 2007.Fecal bacteria in the rivers of the Seine drainage network (France): Sources, fate and modeling. Université Libre de Bruxelles. Bruxelles.

Supardi, I.2003. Lingkungan Hidup dan Kelestariannya. Bandung : Penerbit PT. Alumni.

Urabe, M. 1986. Interaction of Metal Ion with Clays: I. A case study with Cu (II). Applied Clay Science. 30: 199-208

Widodo, Samudro, G., 2012. Studi Penurunan Coliform Mata Air Menggunakan Clay Filter. Teknik Lingkungan FT, UNDIP: Semarang

Wigayati, Etty Marti dan P. Sebayang.1997. Preparasi Keramik Berpori dari Zeolit Alam dan Karakterisasinya. Seminar Nasional Fisika Terapan, Serpong

Wongsakoonka, Watcharapan. 2014. Suitable Types and Constituent Ratios for Clay-Pot Water Filters to Improve the Physical and Bacteriological Quality of Drinking Water. Environment Asia. 7(2) (2014) 117-123 